\title{
RESEARCH
}

Open Access

\section{Interleukin-1 $\beta$ induces CXCR3-mediated chemotaxis to promote umbilical cord mesenchymal stem cell transendothelial migration}

\author{
Yu-Chien Guo ${ }^{1}$, Yun-Hsuan Chiu', Chie-Pein Chen ${ }^{1}$ and Hwai-Shi Wang ${ }^{1 *}$ (D)
}

\begin{abstract}
Background: Mesenchymal stem cells (MSCs) are known to home to injured and inflamed regions via the bloodstream to assist in tissue regeneration in response to signals of cellular damage. However, the factors and mechanisms that affect their transendothelial migration are still unclear. In this study, the mechanisms involved in interleukin-1 $\beta$ (IL-1 $\beta$ ) enhancing the transendothelial migration of MSCs were investigated.

Methods: Immunofluorescence staining and Western blotting were used to observe IL-1 $\beta$-induced CXC chemokine receptor 3 (CXCR3) expression on MSCS. Quantitative real-time PCR and ELISA were used to demonstrate IL-1 $\beta$ upregulated both chemokine (C-X-C motif) ligand 9 (CXCL9) mRNA and CXCL9 ligand secretion in human umbilical vein endothelial cells (HUVECs). Monolayer co-cultivation, agarose drop chemotaxis, and transwell assay were conducted to investigate the chemotaxis invasion and transendothelial migration ability of IL-1 $\beta$-induced MSCs in response to CXCL9.

Results: In this study, our immunofluorescence staining showed that IL-1 $\beta$ induces CXCR3 expression on MSCs. This result was confirmed by Western blotting. Following pretreatment with protein synthesis inhibitor cycloheximide, we found that IL-1 $\beta$ induced CXCR3 on the surface of MSCs via protein synthesis pathway. Quantitative real-time PCR and ELISA validated that IL-1 $\beta$ upregulated both CXCL9 mRNA and CXCL9 ligand secretion in HUVECs. In response to CXCL9, chemotaxis invasion and transendothelial migration ability were increased in IL-1 $\beta$-stimulated MSCs. In addition, we pretreated MSCs with CXCR3 antagonist AMG-487 and P38 MAPK inhibitor SB203580 to confirm CXCR3-CXCL9 interaction and the role of CXCR3 in IL-1 $\beta$-induced chemotaxis invasion and transendothelial migration.

Conclusion: We found that IL-1 $\beta$ induces the expression of CXCR3 through p38 MAPK signaling and that IL-1 $\beta$ also enhances CXCL9 ligand secretion in HUVECs. These results indicated that IL-1 $\beta$ promotes the transendothelial migration of MSCs through CXCR3-CXCL9 axis. The implication of the finding could enhance the efficacy of MSCs homing to target sites.
\end{abstract}

Keywords: Interleukin-1 $\beta$, Umbilical cord mesenchymal stem cell, CXCR3, CXCL9, Transendothelial migration

\footnotetext{
* Correspondence: hswang@ym.edu.tw

${ }^{1}$ Institute of Anatomy and Cell Biology, School of Medicine, National Yang

Ming University, Peitou, Taipei 112, Taiwan, Republic of China

Full list of author information is available at the end of the article
}

(c) The Author(s). 2018 Open Access This article is distributed under the terms of the Creative Commons Attribution 4.0 International License (http://creativecommons.org/licenses/by/4.0/), which permits unrestricted use, distribution, and reproduction in any medium, provided you give appropriate credit to the original author(s) and the source, provide a link to the Creative Commons license, and indicate if changes were made. The Creative Commons Public Domain Dedication waiver (http://creativecommons.org/publicdomain/zero/1.0/) applies to the data made available in this article, unless otherwise stated. 


\section{Background}

Mesenchymal stem cells (MSCs) are known to home to injured and inflamed regions through the bloodstream to promote wound healing and tissue regeneration [1]. Much is known about leukocyte and lymphocyte chemotactic responses and how these cells migrate with blood circulation to sites of injury and inflamed tissues $[2,3]$. Leukocyte homing and migration undergo a series of interactions with endothelial cells (ECs) followed by "transendothelial migration" to enter the target tissue. Several studies have shown that MSCs may possess leukocyte-like, active homing mechanisms that enable them to interact with and migrate across EC monolayers due to injury or inflammation $[4,5]$. It is well known that leukocytes can attach and penetrate through ECs, but the interaction between MSCs and ECs and the factors or chemoattractants that affect their transendothelial migration are not well understood. Although MSC homing and migration have been demonstrated, only a small proportion of systemically administered MSCs actually reaches and remains in the target tissue. To overcome these problems, chemokines and their receptors are now recognized as important mediators of stem cell homing.

Injured and inflamed tissue may release cytokines and growth factors such as transforming growth factor (TGF- $\beta 1)$, tumor necrosis factor (TNF- $\alpha$ ), and interleukins (IL) $[6,7]$. Interleukin-1 $\beta$ (IL-1 $\beta$ ) is a member of the interleukin 1 family and plays a key role in innate immunity and inflammation of multiple tissues and organs. Previous studies have found that IL- $1 \beta$ increases bone marrow (BM)-MSC homing and enhances leukocyte migration [8]. However, IL-1 $\beta$ has been found to diminish osteoblast migration [9]. Some studies also indicated that IL-1 $\beta$ induces upregulation of $\mathrm{CXC}$ chemokine receptor 3 (CXCR3) in different types of cells, such as $\mathrm{T}$ lymphocytes, natural killer cells, and tumor cells [10-14].

CXCR3 is a $G \alpha_{i}$-protein-coupled seven-transmembrane domain chemokine receptor that plays an important role in various immune responses, transendothelial migration, and metastasis. Previous studies have demonstrated that activated CXCR3 is highly expressed on the surface of effector $\mathrm{T}$ cells and is able to regulate $\mathrm{T}$ cell trafficking $[15$, 16]. CXCR3 can specifically bind and respond to three gamma interferon (IFN- $\gamma$ )-induced CXC chemokine families that are chemokine (C-X-C motif) ligand 9 (CXCL9), CXCL10, and CXCL11. Chemokine ligands and their receptors have been implicated in the pathophysiology of numerous autoimmune and inflammatory diseases and in cancer progression and metastasis. Binding of CXCL9, CXCL10, and CXCL11 to CXCR3 triggers various cellular responses, for example, $\beta 1 / \beta 2$ integrin activation, actin cytoskeleton changes, $\mathrm{T}$ cell recruitment, and chemotactic migration [16-19]. Notably, high-level expression of CXCL9 has been shown on some ECs, such as tumor ECs [19] and sclerosis ECs [20]. CXCL9 can be upregulated by TNF- $\alpha$, IFN- $\gamma$, and Toll-like receptors-ligands on human microvascular ECs [21], and CXCL9 can enhance MSC transendothelial migration across murine aortic ECs [22].

MAPKs are a family of serine/threonine kinases and are activated upon their specific substrates at serine and/or threonine residues by a variety of extracellular stimuli including proinflammatory cytokines [23]. A previous study indicated that IL-1 $\beta$ upregulates $G$ protein signaling-4 (RGS4) expression via phosphorylation of p38 MAPK in rabbit colonic smooth muscle cells (SMCs) [24]. Enhancement of CXCL9 expression increases the CXCR3-mediated chemotaxis migration of peripheral blood lymphocytes (PBLs) and T cells through p38 MAPK cascade [25].

To date, the most studied chemokine-chemokine receptor axis in MSC homing to injured and inflamed tissues is CXCR4-SDF-1 $\alpha$. Much research has focused on ways to enhance the expression of CXCR4 on the surface of MSCs to migrate toward chemotactic SDF-1 $\alpha$ secreted at injury sites [26, 27]. Our previous studies have found that tail vein-injected human umbilical cord mesenchymal stem cells (hUCMSCs) migrate to the pancreas in hyperglycemic non-obese diabetic (NOD) mice at higher rates than normal NOD mice even in higher levels of interleukin-1 $\beta$ (IL-1 $\beta$ ) [28] and CXCL9.

In this study, we found that IL-1 $\beta$ induces chemokine receptor CXCR3 expression on the surface of hUCMSCs through p38 MAPK pathway and confirmed that activated human umbilical vein endothelial cells (HUVECs) can release chemokine CXCL9 ligand that acts as a MSC chemoattractant. IL-1 $\beta$ can also promote and accelerate spreading or transmigrating of MSC on HUVECs. A novel CXCR3 antagonist AMG-487 was used to inhibit CXCR3-mediated chemotaxis migration of IL- $1 \beta$-treated MSCs. Taken together, this strategy enhances CXCR3-mediated chemotaxis and transendothelial migration abilities for MSC homing to target sites through the CXCR3-CXCL9 axis.

\section{Methods \\ Cell culture \\ Human umbilical cord mesenchymal stem cell (hUCMSC)}

Human umbilical cord mesenchymal stem cells were obtained from Bioresource Collection and Research Center, Hsinchu, Taiwan. The culturing conditions were modified from previously described methods [29]. Briefly, MSCs were maintained in a low-serum defined medium consisting of 56\% low-glucose Dulbecco's modified Eagle medium (DMEM; Invitrogen, CA, USA), 37\% MCDB 201 (Sigma, MO, USA), 2\% fetal bovine serum (Thermo, Logan, UT), $0.5 \mathrm{mg} / \mathrm{ml}$ of AlbuMAX ${ }^{\oplus}$ (Invitrogen, CA, USA), $1 \times$ insulin-transferrin-selenium-A (Invitrogen, CA, USA), $1 \times$ antibiotic antimycotic solution (Thermo, Logan, UT), $10 \mathrm{nM}$ dexamethasone (Sigma, MO, USA), $50 \mathrm{nM}$ 
L-ascorbic acid 2-phosphate (Sigma, MO, USA), $10 \mathrm{ng} / \mathrm{ml}$ of epidermal growth factor (PeproTech, NJ, USA), and $1 \mathrm{ng} / \mathrm{ml}$ of platelet-derived growth factor-BB (PeproTech, $\mathrm{NJ}$, USA) at $37{ }^{\circ} \mathrm{C}$ and $5 \% \mathrm{CO}_{2}$. When cells reached 70 $80 \%$ confluence, cells were detached using HyQtase (Thermo, Logan, UT) and replated at a ratio of 1:4.

\section{Human umbilical vein endothelial cell (HUVEC)}

Human umbilical vein endothelial cells were purchased from Bioresource Collection and Research Center, Hsinchu, Taiwan. The culture method was modified from protocol described by Gupta et al. [30]. Briefly, HUVECs were cultured on a $1 \%$ gelatin (Sigma, MO, USA)-coated T75 flask, maintained in Dulbecco's modified Eagle medium/Nutrient Mixture F-12 (Life Technologies, NY, USA) supplemented with $2 \%$ fetal bovine serum (Thermo, Logan, UT), $1 \mu \mathrm{g} / \mathrm{ml}$ hydrocortisone (Sigma, MO, USA), $5 \mathrm{ng} / \mathrm{ml}$ epidermal growth factor (PeproTech, NJ, USA), $10 \mathrm{ng} / \mathrm{ml} \mathrm{FGF-2}$ (PeproTech, NJ, USA), $20 \mu \mathrm{g} / \mathrm{ml}$ heparin sulfate (Sigma, MO, USA), $250 \mathrm{ng} / \mathrm{ml}$ insulin (Sigma, MO, USA), and 1× penicillin-streptomycin solution (Thermo, Logan, UT) at $37{ }^{\circ} \mathrm{C}$ and $5 \% \mathrm{CO}_{2}$. When cells reached $80-90 \%$ confluence, they were detached using HyQtase (Thermo, Logan, UT) and replated at a ratio of 1:3.

\section{Cytokines and inhibitors}

MSCs and HUVECs were cultured for $12-16 \mathrm{~h}$ in DMEM containing $0.5 \%$ FBS and $3-4 \mathrm{~h}$ in F-12 containing $1 \%$ BSA, respectively. In our previous study, MSC migration can be significantly enhanced by adding $100 \mathrm{ng} / \mathrm{ml}$ human recombinant interleukin-1 $\beta$ (IL-1 $\beta$ ) [31]. In this study, both MSCs and HUVECs were stimulated with $100 \mathrm{ng} / \mathrm{ml} \mathrm{IL-1 \beta}$ (Peprotech, NJ, USA) for $30 \mathrm{~min}$ and $12 \mathrm{~h}$ individually. The protein synthesis inhibitor cycloheximide (Cayman, USA) was added to MSCs 60 min prior to IL- $1 \beta$ stimulation at a final concentration of $20 \mu \mathrm{g} / \mathrm{ml}$. The CXCR3 antagonist ( \pm )-AMG 487 (Tocris, UK) was added to culture MSC medium $2 \mathrm{~h}$ prior to stimulation at $500 \mathrm{nM}$. The p38 MAPK inhibitor SB203580 (Tocris, UK) was added to MSCs $2 \mathrm{~h}$ prior to stimulation at concentrations of $25 \mu \mathrm{M}, 10 \mu \mathrm{M}$, and $20 \mu \mathrm{M}$, respectively.

\section{MTT cell viability assay}

MSCs were cultured for $12-16 \mathrm{~h}$ in DMEM containing $0.5 \%$ FBS, then the CXCR3 antagonist ( \pm )-AMG 487 $(500 \mathrm{nM})$ and p38 MAPK inhibitor SB203580 $(25 \mu \mathrm{M})$ were added to MSCs $2 \mathrm{~h}$ prior to $30 \mathrm{~min}$ of IL-1 1 (100 ng/ $\mathrm{ml})$ stimulation or $24 \mathrm{~h}$ of CXCL9 $(500 \mathrm{ng} / \mathrm{ml})$ stimulation. HUVECs were cultured for $3-4 \mathrm{~h}$ in F-12 containing $1 \%$ BSA then stimulated with IL-1 $\beta$ for $12 \mathrm{~h}$ or CXCL9 for $24 \mathrm{~h}$. Both MSCs and HUVECs were incubated with $1 \mathrm{mg} / \mathrm{ml}$ MTT reagent, 3-(4,5-dimethylthiazol-2-yl)-2,5-diphenyltetrazolium bromide (SERVA Heidelberg German 20395) in culture medium for $4 \mathrm{~h}$, then suspended in DMSO (Sigma, MO, USA) for $2 \mathrm{~h}$ at $37^{\circ} \mathrm{C}$. The results were detected at a wavelength of $545 \mathrm{~nm}$ using multimode microplate readers (Infinite 200, TECAN).

\section{Quantitative real-time polymerase chain reaction (qPCR)}

After stimulation with IL-1 $\beta$, cells were harvested and total RNA was extracted using TriPure isolation reagent (Bioline, London, UK) according to the manufacturer's instruction. RNA was converted to cDNA with the Tetro cDNA Synthesis kit (Bioline, London, UK). The same amount of cDNA (100 ng) was used in each reaction. The oligonucleotides used for each gene are provided in Additional file 1: Table S1. Gene expression was analyzed by quantitative real-time PCR using SensiFAST CYBR Hi-ROX System (Bioline, London, UK) and each reaction was repeated in triplets.

\section{CXCL9 enzyme-linked immunosorbent assay (ELISA)}

After stimulation with IL-1 $\beta$, the HUVEC condition medium was collected at the time point of $18 \mathrm{~h}$ and $24 \mathrm{~h}$. Quantitation of CXCL9 protein expression was performed using Human CXCL9/MIG Quantikine ELISA Kit (R\&D systems, USA). The results were detected at a wavelength of $450 \mathrm{~nm}$ using multimode microplate readers (Infinite 200, TECAN).

\section{Cell immunofluorescence and image}

Cells were plated in 24-well plates with $12-\mathrm{mm}$ coverslips, cultured for $12-16 \mathrm{~h}$ in DMEM containing $0.5 \%$ fetal bovine serum and then stimulated $100 \mathrm{ng} / \mathrm{ml} \mathrm{IL-1 \beta}$ with or without inhibitor pretreatment. Cells were fixed with PBS containing 4\% $(v / v)$ paraformaldehyde for $15 \mathrm{~min}$ and permeabilized with $0.1 \%$ Triton X-100 in PBS for 15 min. Cells were blocked with 2\% BSA (Sigma, MO, USA) in PBS for $1 \mathrm{~h}$ and incubated with primary anti-CXCR3 antibody (1:200) (Abcam, London, UK) overnight. Cells were incubated with Alexa Fluor 488 secondary antibody (1:200) for $1 \mathrm{~h}$ in room temperature. Cells were then stained with Hoechst 33258 (1:5000) (Sigma, MO, USA) after washing three times with PBS. Samples were mounted with fluorescence mounting medium (Ibidi, Planegg, Germany) and imaged using a fluorescent microscope (DM6000B, Leica) or laser confocal microscope (FV1000, Olympus). The fluorescence intensity was then processed and analyzed using Image J.

\section{Western blotting}

Cells were washed with $1 \times$ PBS before the cytosolic and membrane proteins were fractionated by $M e m-P^{2 m}$ Plus Membrane Protein Extraction Kit (Thermo, IL, USA), according to the manufacturer's instructions. Protein concentration was determined with the Coomassie Plus (Bradford) protein assay reagent (Thermo, IL, USA) 
using multimode microplate readers (Infinite 200, TECAN). Protein samples were resolved with $10 \%$ sodium dodecyl sulfate-polyacrylamide gel electrophoresis (SDS-PAGE) and transferred to polyvinylidene fluoride membranes (Merck, Darmstadt, Germany). Membrane was blocked in 10\% fish gelatin blocking buffer (AMRESCO, OH, USA) for $1 \mathrm{~h}$ and then incubated with the primary anti-CXCR3 antibody (Abcam, London, UK) at 1:3000 dilution at $4{ }^{\circ} \mathrm{C}$ overnight. Pan-cadherin (GeneTex, CA, USA) was used as a cell plasma membrane marker. The blots were washed with Tris-buffered saline with Tween 20 (TBST) and incubated with Rabbit IgG (HRP) (GeneTex, CA, USA) secondary antibody for $1 \mathrm{~h}$ at room temperature. Membranes were washed and then detected by enhanced chemiluminescence substrate using Luminescence Imaging System (LAS-4000, GE, USA).

\section{Monolayer co-cultivation assay}

HUVECs were seeded on $0.1 \%$ gelatin-coated coverslips in 24-well plates and incubated for 24-48 h until cells formed a confluent monolayer. HUVEC monolayers were stained with $8 \mu \mathrm{M}$ Calcein AM (Tocris, UK) in serum-free medium for $30 \mathrm{~min}$ at $37{ }^{\circ} \mathrm{C}$, then gently washed three times with PBS. Prior to co-cultivation, CellTracker ${ }^{\text {ma }}$ Orange (Life Technologies, NY, USA) was added at final concentration of $5 \mu \mathrm{M}$ to the MSC cell suspension. After incubation for $40 \mathrm{~min}$ at $37^{\circ} \mathrm{C}$, MSCs were centrifuged at $800 \mathrm{~g}$ for $2 \mathrm{~min}$, the medium was aspirated, and pellets were washed with PBS three times. For co-cultivation, labeled MSCs were placed on HUVEC monolayers for 30, 60, 180, $240 \mathrm{~min}$. Thereafter, cells were fixed with $4 \%(v / v)$ paraformaldehyde, and morphology and interaction between HUVECs and MSCs in the X-Z and Y-Z plane were analyzed by laser confocal microscope.

\section{Agarose drop chemotaxis assay}

$0.1 \mathrm{~g}$ of low-melting point agarose powder (Basic Life, USA) was added into $20 \mathrm{ml}$ PBS to prepare $0.5 \%$ agarose solution. The solution was heated until boiling and filtered into a 50-ml centrifuge tube immediately. After cooling down to $40{ }^{\circ} \mathrm{C}, 90 \mu \mathrm{l}$ of agarose solution was pipetted into an Eppendorf tube containing $10 \mu \mathrm{l}$ of serum-free medium with or without human CXCL9. Fifty microliters of agarose solution was added as rapidly as possible to gelatincoated 18-mm coverslips in 6-well plates, and the drops were allowed to solidify at $4{ }^{\circ} \mathrm{C}$. Before agarose drop chemotaxis assay, MSCs were cultured for $12-16 \mathrm{~h}$ in DMEM containing 0.5\% FBS, then CXCR3 antagonist $( \pm)$-AMG $487 \quad(500 \mathrm{nM})$ and p38 MAPK inhibitor SB203580 $(25 \mu \mathrm{M})$ were added to MSCs $2 \mathrm{~h}$ prior to IL-1 $\beta$ stimulation. For agarose drop chemotaxis assay, MSCs were then detached with HyQtase (Thermo, Logan, UT), and $2 \times 10^{5}$ cells in serum-free DMEM were plated on coverslips with agarose drop. After $24 \mathrm{~h}$ incubation at $37^{\circ} \mathrm{C}$, the number of migrated MSCs was counted under complete agarose drop by microscopy.

\section{In vitro transendothelial migration assay}

Transwell inserts with $8-\mu \mathrm{m}$ pore size were coated with $0.5 \%$ gelatin, and $2 \times 10^{4}$ HUVECs were seeded onto the membrane of each transwell insert, incubated over 2 days until forming a HUVEC monolayer and then activated with or without IL-1 $\beta$ for $12 \mathrm{~h}$ in serum-free F-12 containing $1 \%$ BSA. Before transendothelial migration assay, MSCs were cultured for 12-16 h in DMEM containing 0.5\% FBS, then CXCR3 antagonist ( \pm )-AMG $487(500 \mathrm{nM})$ and p38 MAPK inhibitor SB203580 $(25 \mu \mathrm{M})$ were added to MSCs $2 \mathrm{~h}$ prior to IL-1 $\beta$ stimulation. MSCs were then detached with HyQtase and stained with CellTracker ${ }^{\mathrm{rm}}$ Orange at a concentration of $10 \mu \mathrm{M}$. After MSCs were incubated for $40 \mathrm{~min}$ at $37^{\circ} \mathrm{C}$, then spun down at $800 \mathrm{~g}$ for $2 \mathrm{~min}$, the medium was aspirated and the pellets were washed with PBS three times. For transendothelial migration assay, $1.5 \times 10^{4}$ labeled MSCs in 200- $\mu \mathrm{l}$ serum-free DMEM were loaded into the upper chamber; meanwhile, $500-\mu \mathrm{l}$ serum-free F-12 with or without $50 \mathrm{ng} / \mathrm{ml}$ human CXCL9 was added to the lower chamber. After $24 \mathrm{~h}$ incubation at $37^{\circ} \mathrm{C}$, non-migrated cells in the lower chamber were gently removed with cotton swabs. A number of MSCs which had migrated through to the lower chamber were fixed and stained with Hoechst 33258, and HUVECs were stained with Hoechst 33258 without CellTracker ${ }^{\mathrm{mi}}$ Orange to distinguish two types of cells. Fluorescence microscopy was used to count the number of migrated cells in five randomly selected fields.

\section{Statistical analysis}

Statistical analyses were performed using Prism 5 software. Quantitation data were analyzed by Student's $t$ test and one-way ANOVA. $P$ values $<0.05$ were considered statistically significant.

\section{Results}

\section{IL-1 $\beta$ induces rapid CXCR3 expression on the surface of} MSCs

To determine the location of chemokine receptor CXCR3 after stimulation with $100 \mathrm{ng} / \mathrm{ml} \mathrm{IL-1 \beta}$ for 15 , 30, and $180 \mathrm{~min}$, immunofluorescence staining was performed (Fig. 1a). The staining fluorescence intensity was quantitated (Fig. 1b). The results showed that CXCR3 is an integral membrane protein and can be upregulated on the cell surface of MSCs by IL-1 $\beta$. In addition, MSCs expressed the highest CXCR3 levels on the surface after $30 \mathrm{~min}$ of stimulation in comparison with 15 and $180 \mathrm{~min}$ of stimulation. To further confirm whether IL-1 $\beta$ could induce CXCR3 expression on protein levels in MSCs, membrane and cytosolic proteins were fractionated using Mem-PER ${ }^{\mathrm{Tm}}$ Plus Membrane Protein Extraction Kit and then detected using Western blotting. We found that CXCR3 was 
(A)
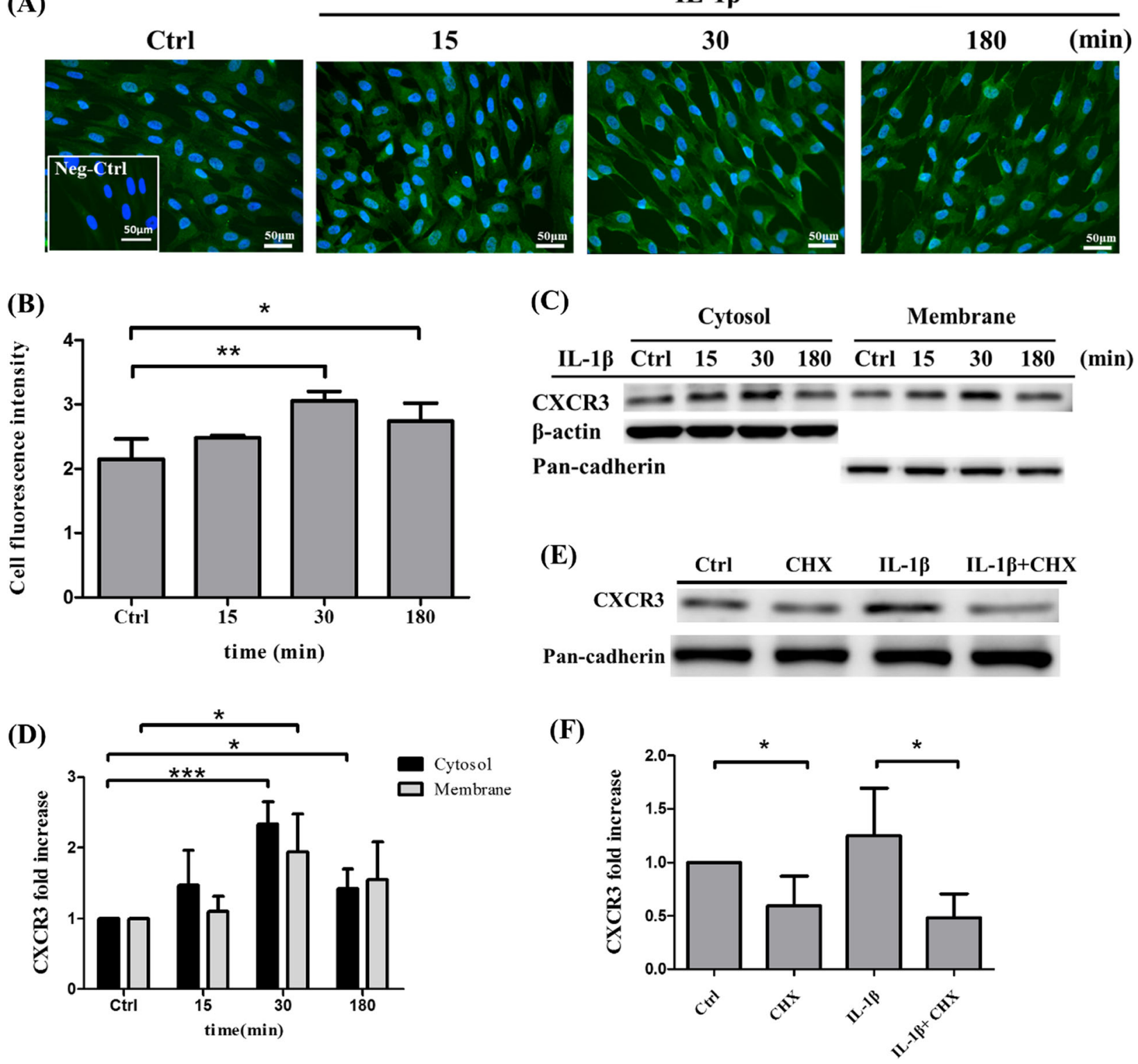

Fig. $1 \mathrm{lL}-1 \beta$ induces CXCR3 expression on MSCs. a Immunofluorescence staining of CXCR3 (green) in control MSCs and MSCs stimulated with $100 \mathrm{ng} / \mathrm{ml} \mathrm{IL-1 \beta}$ at 15, 30, and $180 \mathrm{~min}$; cellular nuclei were stained in blue. Negative control: CXCR3 antibody without secondary antibody. Scale bar: $50 \mu \mathrm{m}$. b Quantitative fluorescence intensity results analyzed by Image J; 10 cells were quantitated in each experiments of control MSCs and MSCs stimulated with $100 \mathrm{ng} / \mathrm{ml} \mathrm{IL-1 \beta}$ at 15, 30, and $180 \mathrm{~min}$. The data represent mean \pm SD $(n=3)$. Statistical analysis was determined by Student's $t$ test and one-way ANOVA. ${ }^{*} P<0.05$, ${ }^{*} P<0.01$. c MSCs were stimulated with $100 \mathrm{ng} / \mathrm{ml} \mathrm{IL}-1 \beta$ at 15, 30, and $180 \mathrm{~min}$. The cytosolic and membrane protein were fractionated by Mem-PERTM Plus Membrane Protein Extraction Kit, then the expression of CXCR3 (41 kDa) protein was detected by Western blotting. $\beta$-actin was used as a cytosolic marker whereas pan-cadherin was used as a cell membrane marker. $\mathbf{d}$ Quantitative results of the Western blotting of CXCR3 cytosolic and membrane protein expression of $\mathbf{c}$. The data represent mean \pm SD $(n=3)$. Statistical analysis was determined by Student's $t$ test and one-way ANOVA. ${ }^{*} P<0.05$ versus control, ${ }^{* *} P<0.001$ versus control. e MSCs were pretreated with protein synthesis inhibitor, cycloheximide, at concentration of $20 \mu \mathrm{g} / \mathrm{ml}$, then stimulated with IL-1 $\beta$ for $30 \mathrm{~min}$. The expression of CXCR3 membrane protein was detected by Western blotting. $\mathbf{f}$ Quantitative results of the Western blotting of CXCR3 membrane protein expression of $\mathbf{e}$. The data represent mean \pm SD $(n=3)$. Statistical analysis was determined by Student's $t$ test and one-way ANOVA. * $P<0.05$

upregulated both in cytosolic and membrane proteins compared with control in MSCs after incubation with IL-1 $\beta$ with significant enhancement at 30 min rather than 15 and $180 \mathrm{~min}$ (Fig. 1c, d). The cell viability assay indicated no significant change in IL- $1 \beta$-treated MSCs in comparison to the control group, which suggests that IL-1 $\beta$-induced CXCR3 expression was not affected by cell proliferation (Additional file 2: Figure S1A). To 
determine CXCR3 protein production through intracellular translocation or protein synthesis, MSCs were pretreated with cycloheximide for $1 \mathrm{~h}$ and analyzed by Western blotting to identify CXCR3 expression. Cycloheximide is a protein synthesis inhibitor and has been shown to block the translation elongation in organisms [32]. The results indicated that the level of CXCR3 protein expression in IL-1 $\beta$-treated cells was higher than that in non-treated cells. Meanwhile, pretreatment of $20 \mu \mathrm{g} / \mathrm{ml}$ cycloheximide of MSCs significantly suppressed IL- $1 \beta$-induced CXCR3 protein expression in membrane (Fig. 1e, f). The cell viability assay indicated no significant change in IL-1 $\beta$, cycloheximide-treated MSCs in comparison to control MSCs. The results show that this concentration of IL-1 $\beta$ and cycloheximide did not lead to cell death (Additional file 2: Figure S1A). We thus demonstrated that the cell surface expression of CXCR3 induced by IL- $1 \beta$ is apparently dependent upon de novo protein synthesis.

\section{IL-1 $\beta$ upregulates CXCL9 expression in HUVECs}

To identify the relevance of CXCL9 expression by IL-1 $\beta$ in HUVEC, SYBR Green quantitative real-time PCR was performed. Figure 2a shows that the level of CXCL9 mRNA transcript in IL-1 $\beta$-treated cells was higher than that in non-treated cells. CXCL9 mRNA peaked at $12 \mathrm{~h}$ fourfold above the control group and then decreased by $24 \mathrm{~h}$. To further evaluate whether HUVECs could produce CXCL9 ligand proteins in response to IL-1 $\beta$, ELISA assay was used to detect the secretion level of CXCL9 ligand protein in the condition medium of IL-1 $\beta$-treated HUVECs. After treatment with IL- $1 \beta$ for $24 \mathrm{~h}$, release of extracellular CXCL9 ligand protein was observed (Fig. 2b). These finding were consistent with our quantitative real-time PCR results (Fig. 2a). Thus, we confirmed that IL-1 $\beta$ could upregulate both CXCL9 mRNA and CXCL9 ligand secretion in HUVECs. The cell viability assay indicated no significant change in IL- $1 \beta$-treated HUVECs in comparison to the control group. The results show that IL-1 $\beta$-induced HUVEC expression was not affected by cell viability (Additional file 2: Figure S1B).

\section{Effects of IL-1 $\beta$ in morphology and interaction between HUVECS and MSCs}

After we finished our investigation of CXCR3 expression on MSCs and CXCL9 ligand secretion in HUVECs, we further investigated the interaction between MSCs and HUVECs by using a co-cultivation approach. As shown in Fig. 3a, b, we observed time-related changes in the morphology of the MSCs. Figure 3a shows that MSCs began to attach to HUVECs and the cell form of cytoplasmic offshoot appeared at the cell edge after $60 \mathrm{~min}$, at which point the MSCs became more flattened and adhered to the HUVEC monolayer. When MSCs were stimulated with IL-1 $\beta$ for $30 \mathrm{~min}$, we found that MSCs attached and adhered to HUVECs in less time. IL-1 $\beta$-treated MSCs extended filopodia and integrated into the edge of HUVECs compared with control after 60 min (Fig. 3a). Furthermore, IL-1 $\beta$-treated MSCs could perform faster transendothelial migration than control MSCs after $240 \mathrm{~min}$ (Fig. 3a). After IL-1 $\beta$ treatment for $180 \mathrm{~min}$, MSCs extended long plasmic filopodia and integrated into the HUVEC monolayer, and after $240 \mathrm{~min}$, the IL-1 $\beta$-treated MSCs penetrated and transmigrated underneath HUVECs (Fig. 3b).

\section{CXCL9 enhances MSC chemotaxis migration via CXCR3- mediated MSC chemotaxis invasion and MSC transendothelial migration induced by IL-1 $\beta$}

It has been found that CXCL9 could enhance the adhering, crawling, and spreading of murine MSCs [19] and enhance cell migration through CXCR3-mediated chemotaxis and
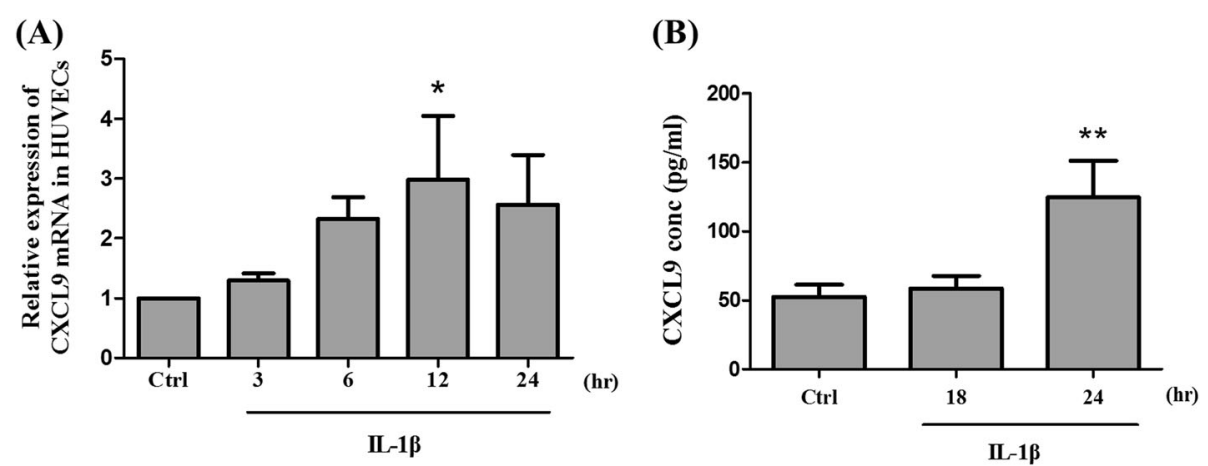

Fig. 2 Effects of IL-1 $\beta$ in HUVECs on CXCL9 mRNA and CXCL9 ligand secretion. a HUVECs were stimulated with $100 \mathrm{ng} / \mathrm{ml}$ IL-1 13 at the time point of $3,6,12$, and $24 \mathrm{~h}$. The CXCL9 mRNA expression was detected using quantitative real-time PCR. $\mathbf{b}$ HUVECs were stimulated with IL-1 $\beta$ then the HUVEC conditioned medium was collected at 18 and $24 \mathrm{~h}$. The CXCL9 ligand protein was detected by ELISA to quantify the release of CXCL9 in supernatants. The data represent mean \pm SD $(n=3)$. Statistical analysis was determined by Student's $t$ test and one-way ANOVA. ${ }^{*} P<0.05$ versus control, ${ }^{* *} P<0.01$ versus control 

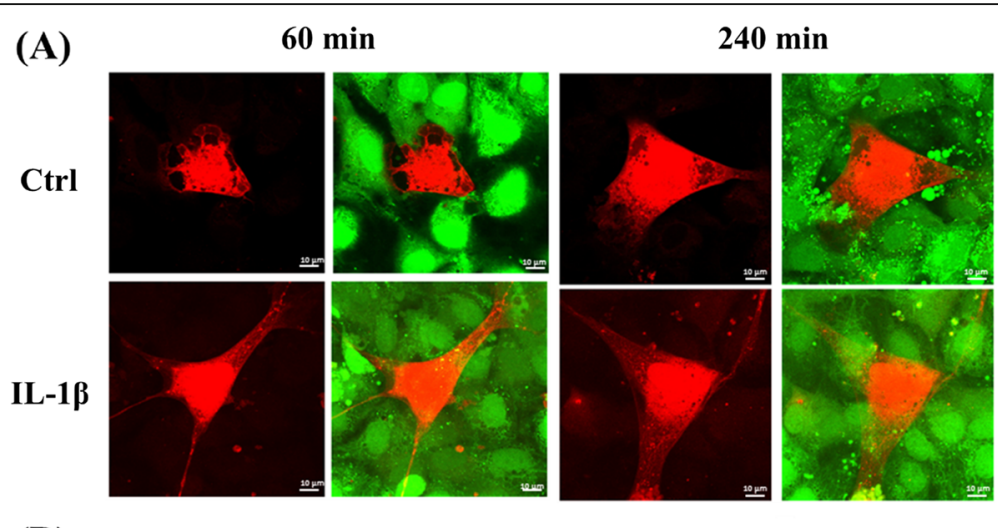

(B)
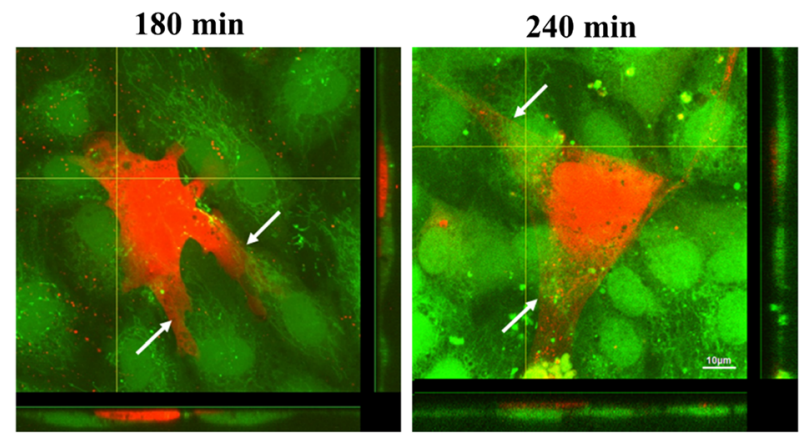

Fig. 3 Effects of IL-1ß in morphology and interaction between HUVECs and MSCs. Labeled MSCs with CellTracker ${ }^{\text {TM }}$ Orange were seeded on HUVECs stained with Calcein AM and co-cultivated for 30 to $240 \mathrm{~min}$. After a period of $60 \mathrm{~min}$, MSCs attached to HUVECs and the morphology were still spherical but developed form of cytoplasmic offshoot. a After $60 \mathrm{~min}, \mathrm{MSC}$ became flattened and adhered to HUVEC monolayer. IL-1 $\beta$ promoted adhesion (left, $60 \mathrm{~min}$ ) and transendothelial migration abilities (right, $240 \mathrm{~min}$ ) of MSCs. b After 180 and 240 min, MSCs extended long plasmic filopodia and integrated into the HUVEC monolayer. Orthogonal projections illustrate that MSCs inserted into HUVEC monolayer (left, $180 \mathrm{~min}$ ) and formation of filopodia caused transendothelial migration (right, $240 \mathrm{~min}$ ). Arrows indicate MSC migration through the HUVEC. Horizontal bar: XZ plane of confocal image stack; vertical bar: YZ plane of confocal image stack. Scale bar $=10 \mu \mathrm{m}$

transendothelial migration $[19,22]$. We examined whether CXCL9 could also induce MSC chemotaxis migration by counting migrated MSCs into agarose drop using agarose drop chemotaxis assay. The results showed that CXCL9 significantly enhanced MSC chemotaxis migration in a dose-dependent manner (Fig. 4a, b). AMG487 is a small molecule antagonist of CXCR3 that can inhibit binding of CXCR3 ligands and cell metastasis. To determine whether AMG484 could inhibit MSC chemotaxis in response to $50 \mathrm{ng} / \mathrm{ml}$ CXCL9, MSCs were pretreated with AMG487 for $2 \mathrm{~h}$ and migrated MSCs were counted under agarose drop after $24 \mathrm{~h}$ CXCL9 induction by agarose drop chemotaxis assay. As shown in Fig. 4c, d, CXCL9 significantly enhanced chemotaxis invasion ability to pass through agarose drop in comparison with the control group. Meanwhile, pretreatment of AMG-487 of MSCs significantly suppressed chemotaxis invasion abilities of MSCs in a dosedependent inhibition. To further examine the effects of AMG-487 in CXCR3-mediated MSC chemotaxis invasion induced by IL-1 $\beta$, MSCs were pretreated with AMG- 487 for $2 \mathrm{~h}$ prior to $30 \mathrm{~min}$ IL-1 $\beta$ stimulation. The results showed that IL-1 $\beta$, CXCL9, or IL-1 $\beta$ plus CXCL9 significantly enhanced chemotaxis invasion ability of
MSCs in comparison with the control group, and these effects could be blocked by pretreatment with AMG-487. Moreover, there was no significant difference in pretreatment with AMG-487 alone in comparison to the control group (Fig. 4e, f). The cell viability assay suggests that there was no significant change in AMG487treated MSCs in comparison to control MSCs. The results show that this concentration of AMG487 did not lead to cell death (Additional file 2: Figure S1B). We thus demonstrated that this antagonist significantly suppressed CXCR3-mediated MSC chemotaxis invasion induced by IL-1 $\beta$ in response to CXCL9.

\section{CXCR3 antagonist inhibits CXCR3-mediated MSC} transendothelial migration induced by IL-1 $\beta$

In order to assess if MSCs are able to transmigrate through ECs, HUVECs were grown on gelatin-coated membrane of transwells. MSCs were pretreated with AMG-487 for $2 \mathrm{~h}$ prior to $30 \mathrm{~min}$ of IL-1 $\beta$ stimulation and HUVECs were also treated with IL- $1 \beta$ for $12 \mathrm{~h}$. This study used transendothelial migration assay to investigate the transendothelial migration ability of MSCs from the upper chamber to lower chamber after $16 \mathrm{~h}$ incubation. In Fig. 5a, b, IL-1 $\beta$, CXCL9, 


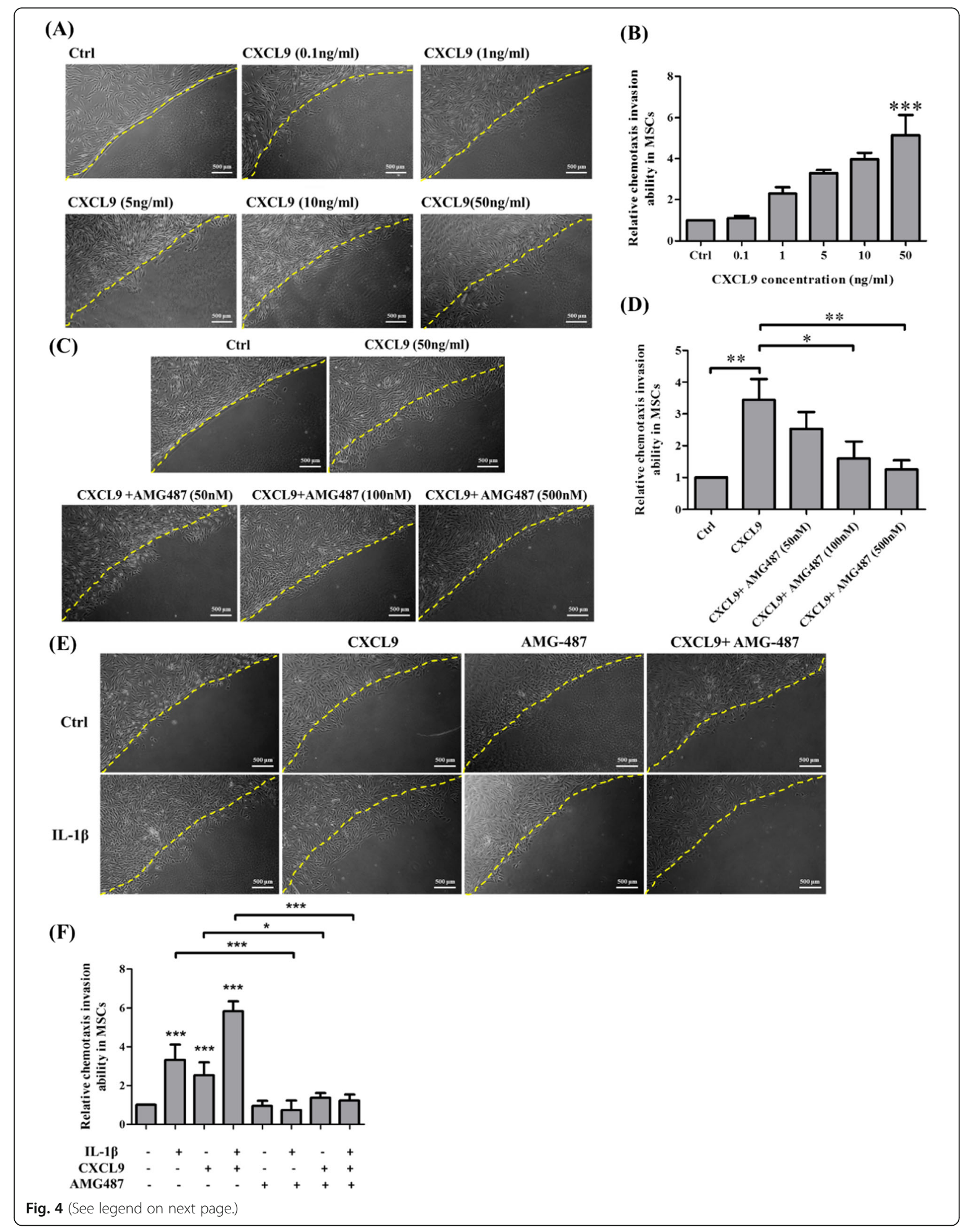


(See figure on previous page.)

Fig. 4 CXCL9 induces MSCs chemotaxis invasion and the effects of CXCR3 antagonist in CXCR3-mediated MSC chemotaxis invasion induced by IL-1 $\beta$. a MSCs were plated on gelatin-coated coverslips in 6-well plates with a $0.5 \%$ agarose drop supplemented with different concentrations of CXCL9. After incubation for $24 \mathrm{~h}, \mathrm{CXCL9}$ directed chemotaxis of MSCs in agarose drop assay for chemotactic invasion. Scale bars $=500 \mu \mathrm{m}$. $\mathbf{b}$ Quantitative results showing the chemotaxis invasion ability of MSCs migrated under agarose drop. The data represent mean \pm SD $(n=3)$. Statistical analysis was determined by Student's $t$ test and one-way ANOVA. ${ }^{* * *} P<0.001$. c MSCs were pretreated with AMG-487 for $2 \mathrm{~h}$ and plated on coverslips in 6-well plates with a $0.5 \%$ agarose drop supplemented with $50 \mathrm{ng} / \mathrm{ml}$ CXCL9. After incubation for 24 h, CXCL9 directed chemotaxis of MSCs in agarose drop assay for chemotactic invasion. Scale bars $=500 \mu \mathrm{m}$. $\mathbf{d}$ Quantitative results showing the chemotaxis invasion ability of MSCs migrating under agarose drop. The data represent mean \pm SD $(n=3)$. Statistical analysis was determined by Student's $t$ test and one-way ANOVA. ${ }^{*} P<0.05,{ }^{* * *} P<0.001$. e MSCS were pretreated or non-pretreated AMG-487 and stimulated with or without IL-1 $\beta$ for 30 min. After pre-activation, MSCs were plated on agarose drop supplemented with the presence or absence of $50 \mathrm{ng} / \mathrm{ml} \mathrm{CXCL9}$ for $24 \mathrm{~h}$. Scale bars $=500 \mu \mathrm{m}$. f Quantitative results showing the chemotaxis invasion ability of MSCs migrated under agarose drop. The data represent mean \pm SD $(n=3)$. Statistical analysis was determined by Student's $t$ test and oneway ANOVA. ${ }^{*} P<0.05,{ }^{* * *} P<0.001$

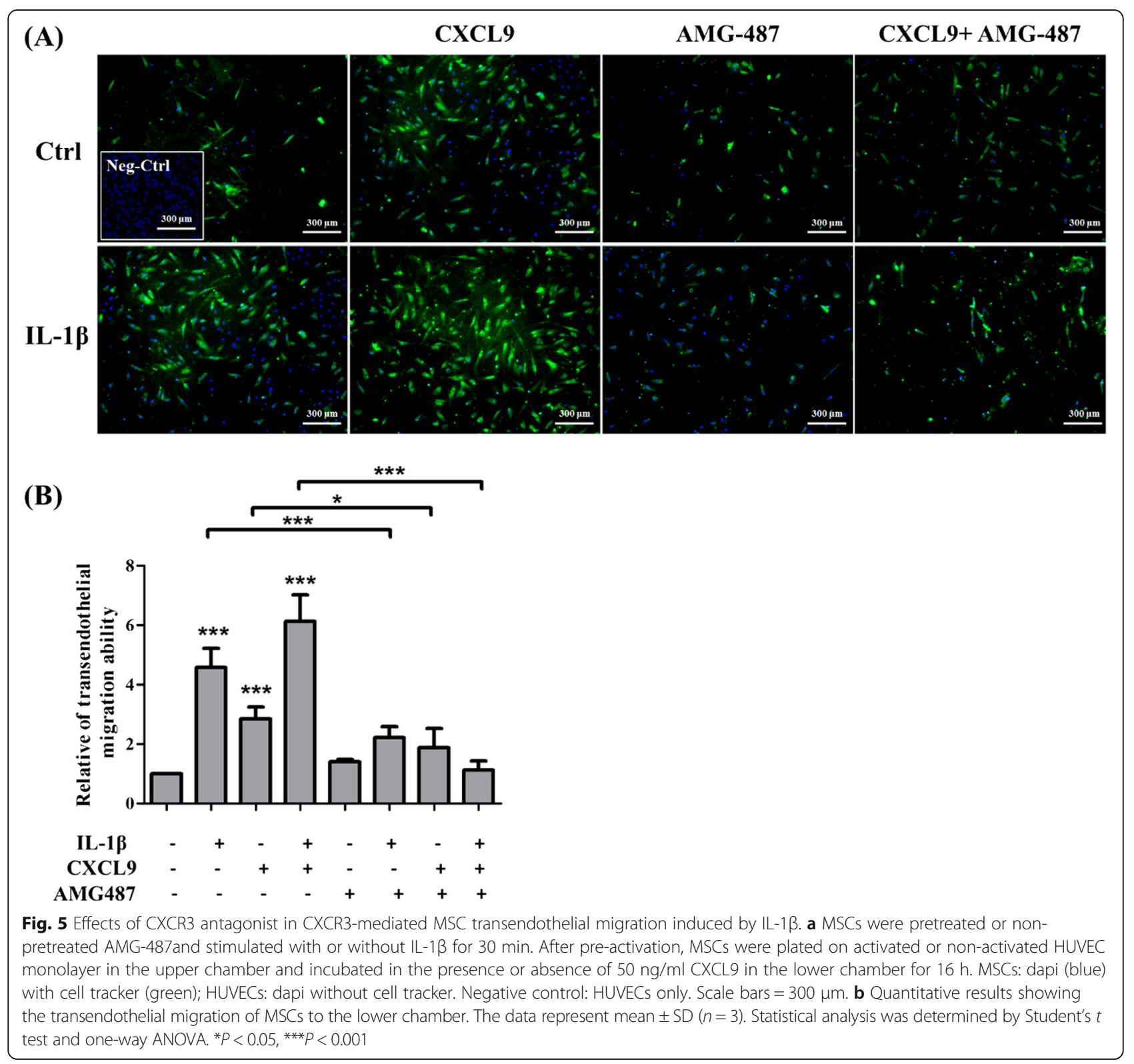


or IL-1 $\beta$ plus CXCL9 significantly enhanced the transendothelial migration ability of MSCs in comparison with control MSCs, and these effects could be markedly attenuated by pretreatment with AMG-487. These findings were consistent with our chemotaxis assay. The cell viability assay was performed and indicated no significant change in response to $50 \mathrm{ng} / \mathrm{ml} \mathrm{CXCL9}$ in comparison to the control group in both MSCs and HUVECs (Additional file 2: Figure $\mathrm{S1C}$ ). These results suggested that cell migration was not affected by cell proliferation and that this concentration of CXCL9 did not lead to cell death.

\section{The p38 MAPK signaling is involved in CXCR3-mediated MSC chemotaxis invasion and MSC transendothelial migration induced by IL-1 $\beta$}

Previous studies have found that IL-1 $\beta$ induced many kinds of protein expression such as MMP-9 and ICAM-1 through p38 MAPK activation [33, 34]. To investigate whether p38 MAPK signaling was also involved in IL-1 $\beta$-induced CXCR3 expression on MSCs, MSCs were pretreated with $25 \mu \mathrm{M}$ p38 MAPK inhibitor SB203580 for $2 \mathrm{~h}$ prior to $30 \mathrm{~min}$ of IL- $1 \beta$ stimulation. CXCR3 protein expression was analyzed and levels in IL-1 $\beta$-treated cells were higher than those in non-treated cells. Meanwhile, pretreatment of $25 \mu \mathrm{M}$ SB203580 of MSCs significantly suppressed IL-1 $\beta$-induced CXCR3 protein expression both in the cytosol and membrane (Fig. 6a, b). These results confirm that IL-1 $\beta$ induced CXCR3 protein expression on MSCs via the p38 MAPK signaling pathway.

To determine the relevance of $\mathrm{p} 38$ MAPK signaling in CXCR3-mediated MSC chemotaxis invasion induced by IL-1 $\beta$, MSCs were pretreated with p38 MAPK inhibitor SB203580 for $2 \mathrm{~h}$ prior to $30 \mathrm{~min}$ of IL-1 $\beta$ stimulation. The results showed that IL-1 $\beta$, CXCL9, or IL- $1 \beta$ plus CXCL9 significantly enhanced chemotaxis invasion abilities of MSCs in comparison with control MSCs. Inhibition of p38 MAPK signaling also significantly attenuated the chemotaxis invasion abilities of IL-1 $\beta$-treated and IL- $1 \beta$ plus CXCL9-treated MSCs, but did not significantly inhibit the chemotaxis invasion ability of CXCL9treated MSCs. Moreover, there was no significant difference in pretreatment with SB203580 alone in comparison to the control group (Fig. 6c, d). The cell viability assay showed no significant change in SB203580-treated MSCs in comparison to control MSCs. The results indicate that this concentration of SB203580 did not lead to cell death (Additional file 2: Figure S1A). These studies show that IL-1 $\beta$ upregulated CXCR3 expression on MSCs via p38 MAPK signaling and is also involved in IL-1 $\beta$-induced MSC chemotaxis invasion. In order to examine the role of p38 MAPK signaling in CXCR3-mediated MSC transendothelial migration induced by IL- $1 \beta$, MSCs were pretreated with p38 MAPK inhibitor SB203580 for $2 \mathrm{~h}$ prior to $30 \mathrm{~min}$ of IL-1 $\beta$ stimulation. HUVECs were also treated with IL-1 $\beta$ for $12 \mathrm{~h}$. We then investigated the transendothelial migration abilities of MSCs to transmigrate across HUVECs from the upper chamber to the lower chamber after 16 h. As shown in Fig. 6e, f, treatment with IL-1 $\beta$ and IL-1 $\beta$ plus CXCL9 significantly enhanced transendothelial migration abilities of MSCs in comparison to control MSCs. The effect of transendothelial migration induced by IL-1 $\beta$ and IL-1 $\beta$ plus CXCL9 was attenuated when SB203580 was added to MSCs (Fig. 6e, f). These findings are consistent with our chemotaxis assay. We thus demonstrated that IL- $1 \beta$-induced MSC CXCR3 expression is mediated by p38 MAPK signaling, then enhances the MSC transendothelial migration.

\section{Discussion}

Mesenchymal stem cells (MSCs) migrate toward injured and inflamed tissue via the bloodstream, possibly attracted by several pro-inflammatory cytokines. Migration and homing involve MSCs attaching to and moving through ECs to the target region to reduce inflammation. During inflammation, ECs upregulate cell surface adhesion molecules and chemoattractants to enhance the transmigration ability of cells $[21,22]$. Our previous study has shown that vein-injected MSCs prefer migrating to the pancreas in non-obese diabetic (NOD) mice rather than in normal mice. In addition, higher pancreatic levels of IL-1 $\beta$ were detected in hyperglycemic NOD mice than in normal NOD mice in an ELISA assay [28].

Some studies have shown that IL- $1 \beta$ could induce upregulation of CXC chemokine receptor 3 (CXCR3) in T cells and tumor cells. Previous research reported that CXCR3specific ligand, CXCL9, a cell chemoattractant expressed in some ECs, can be upregulated in inflammatory microenvironment [21]. Several cell adhesion molecules and chemokines such as ICAM-1 and CXCL5 have been found to be expressed by HUVEC in response to IL- $1 \beta$ stimulation at mRNA levels. However, the expression of chemokine CXCL9 on IL-1 $\beta$-stimulated HUVEC has not yet been characterized. Our cytokine array data showed that CXCL9 was highly expressed in the pancreas of NOD mice in comparison with normal mice (data not shown). Moreover, we found that MSCs express the CXCR3 chemokine receptor and can be upregulated by adding IL- $1 \beta$. IL- $1 \beta$ is a pro-inflammatory cytokine and has been associated with inflammation [35] and tissue injury [36]. We then hypothesized that IL-1 $\beta$-induced expression of CXCL9 in ECs and that IL-1 $\beta$-induced CXCR3 expression on membrane of MSCs are related to MSC migration toward injured and inflamed tissue via the bloodstream. Therefore, MSCs stimulated with IL-1 $\beta$ prior to local implantation or intravenous delivery would be a better therapeutic strategy.

Our qPCR result indicates that CXCL9 ligands significantly increased (threefold) in IL-1 $\beta$-treated HUVECs in 


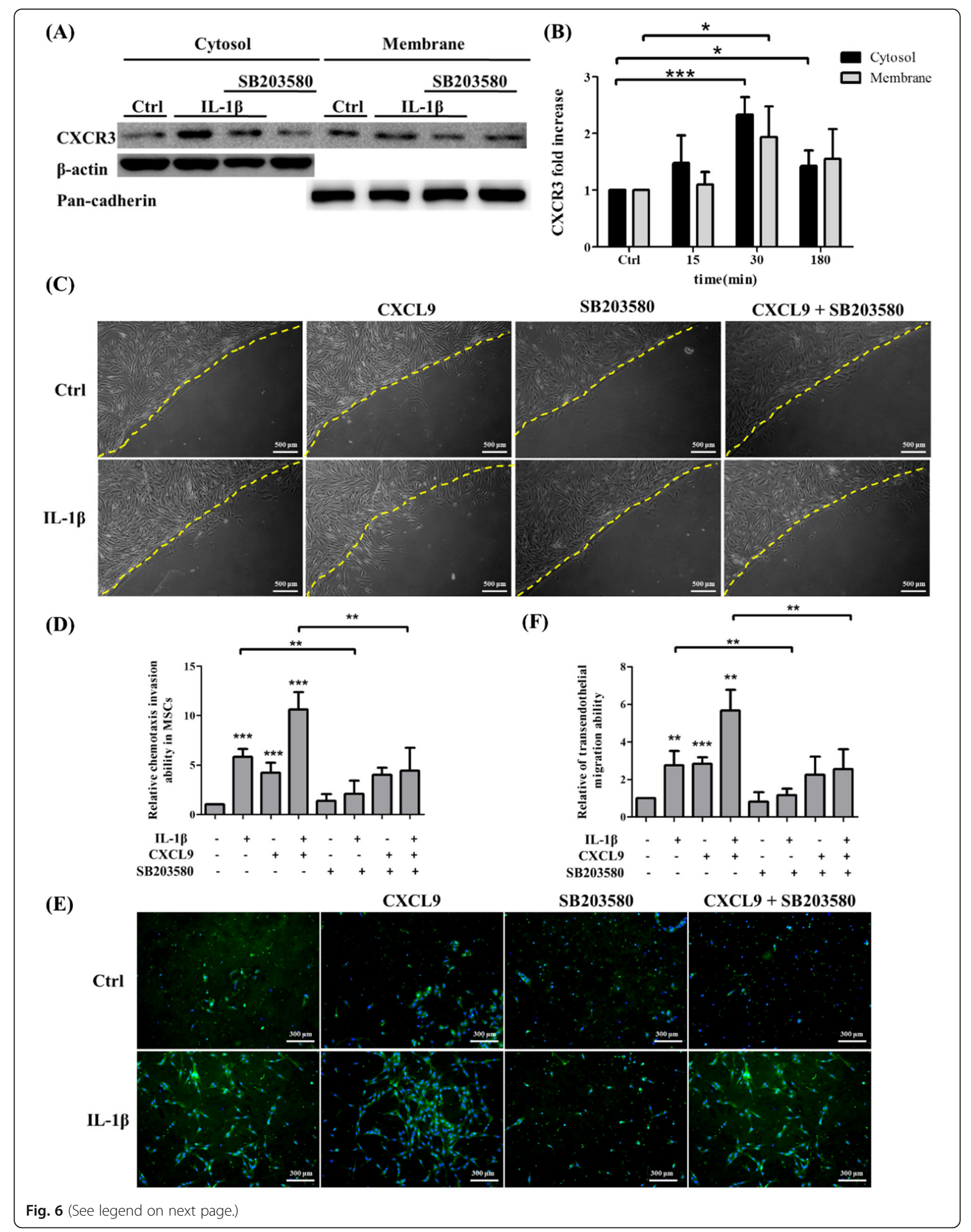


(See figure on previous page.)

Fig. 6 p38 MAPK signaling pathway is involved in CXCR3 protein expression in MSCs, CXCR3-mediated chemotaxis invasion, and transendothelial migration induced by IL-1 3 . a MSCs were pretreated with p38 MAPK inhibitor SB203580, at a concentration of 25 uM, then stimulated with IL-1 $\beta$ for $30 \mathrm{~min}$. The expression of CXCR3 cytosolic and membrane protein were detected by Western blotting. $\mathbf{b}$ Quantitative results of the Western blotting of CXCR3 cytosolic and membrane protein expression of $\mathbf{a}$. The data represent mean \pm SD $(n=3)$. Statistical analysis was determined by Student's $t$ test and one-way ANOVA. ${ }^{*} P<0.05$, ${ }^{* *} P<0.001$. c MSCs were pretreated or non-pretreated with SB203580 and stimulated with or without IL-1 13 for $30 \mathrm{~min}$. After pre-activation, MSCs were plated on agarose drop supplemented with the presence or absence of $50 \mathrm{ng} / \mathrm{ml} \mathrm{CXCL9}$ for $24 \mathrm{~h}$. Scale bars = $500 \mu \mathrm{m}$. d Quantitative results showing the chemotaxis invasion ability of MSCs migrated under agarose drop. The data represent mean \pm SD $(n=3)$. Statistical analysis was determined by Student's $t$ test and one-way ANOVA. ${ }^{* *} P<0.01,{ }^{* *} P<0.001$. e MSCs were pretreated or non-pretreated with p38 MAPK inhibitor and stimulated with or without IL-1 $\beta$ for 30 min. After pre-activation, MSCs were plated on activated or non-activated HUVEC monolayers in the upper chamber and incubated in the presence or absence of $50 \mathrm{ng} / \mathrm{ml} \mathrm{CXCL9}$ in the lower chamber for $16 \mathrm{~h}$. Scale bars $=300 \mu \mathrm{m}$. $\mathbf{f}$ Quantitative results showing the transendothelial migration ability of MSCs migrated to the lower chamber. The data represent mean \pm SD $(n=3)$. Statistical analysis was determined by Student's $t$ test and one-way ANOVA. ${ }^{* *} P<0.01,{ }^{* *} P<0.001$

comparison to non-treated HUVECs. The IL-1 $\beta$-induced mRNA expression of CXCL9 is further supported by ELISA assay. Expression of CXCL9 ligand in the culture supernatants is 2.5 -fold higher than control in IL-1 $\beta$ treated HUVECs. Our immunofluorescence staining and Western blotting data show that CXCR3 expression is upregulated by IL- $1 \beta$ in both the cytosol and membrane of MSCs. After pretreatment with protein synthesis inhibitor cycloheximide, we found that cycloheximide suppressed IL-1 $\beta$-induced rapid and transient activation of CXCR3 on cell surface of MSCs in $30 \mathrm{~min}$. In Additional file 3: Figure S2, we also show long-term stimulation of IL- $1 \beta$ in MSCs by immunofluorescence staining. At 6-, 12-, and 24-h periods of time, there was no significant difference in the cytosol and membrane between non-treated and IL-1 $\beta$ treated MSCs. These results suggest that IL-1 $\beta$ induces CXCR3 expression on cell surface of MSCs via protein synthesis.

It has been observed that co-culture of non-activated MSCs and TNF- $\alpha$-activated ECs and bone marrowMSCs showed morphological changes and transmigrated through endothelial monolayers with filopodia $[4,5,37]$. However, there are no studies of in vitro adhesion and migration of co-cultured IL-1 $\beta$-stimulated ECs and

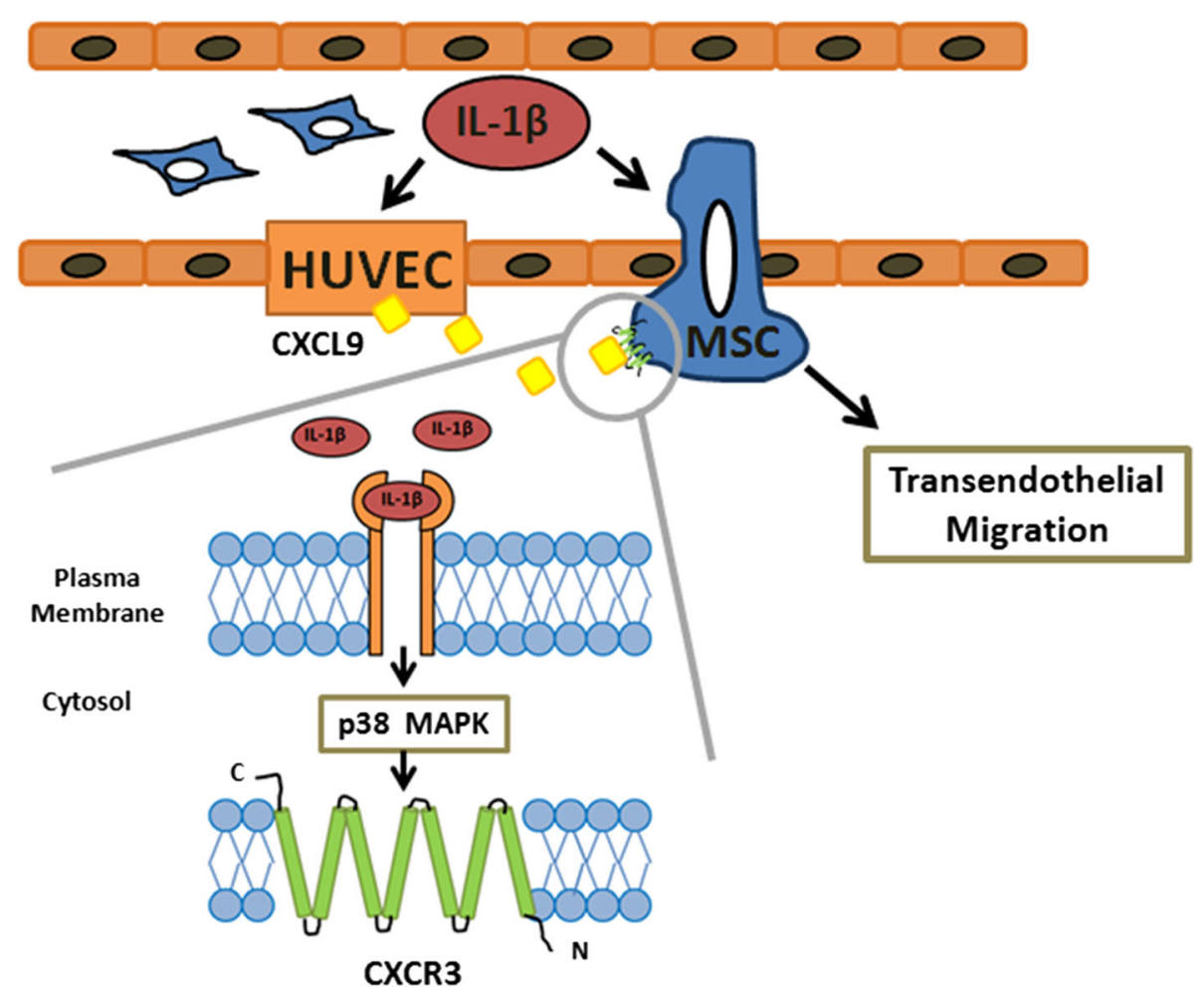

Fig. 7 Schematic diagram of IL-1 $\beta$ signaling pathway in CXCR3-mediated MSC transendothelial migration. A schematic diagram depicts the proposed role of IL-1 $\beta$ signaling pathway in MSC transendothelial migration. The process of cell migration is initiated by IL-1 $\beta$ through p38 MAPK-induced expression of CXCR3 in MSCs in response to CXCL9 
MSCs. Our monolayer co-cultivation assay shows that the time required for human Wharton's jelly-derived MSCs to attach to HUVECs (within $30 \mathrm{~min}$ ) is faster than bone marrow-derived MSCs (2 h) [38] under normal conditions. IL- $1 \beta$ stimulation for $30 \mathrm{~min}$ significantly facilitates MSC attachment and transendothelial migration efficiency. Non-treated MSCs extended long podia and embed into the edge of HUVECs at $240 \mathrm{~min}$, while IL-1 $\beta$-treated MSCs transmigrated underneath HUVEC monolayers at the same time.

CXCL9 has been shown to induce chemotaxis in many cells such as melanoma cells [19], T cells [39], and HEK293 cells [40]. In this study, we embed CXCL9 into agarose gel to simulate an inflamed environment. MSCs invade into agarose and migrate under agarose drop in response to CXCL9. We confirmed that CXCL9 significantly enhances MSC chemotaxis migration in a dose-dependent manner by agarose drop assay. Since CXCL9 does not influence cell proliferation and survival (Fig. 5), these results confirm that CXCL9 is a chemoattractant for MSCs. In addition, CXCR3 antagonist AMG-487 significantly suppresses CXCR3-mediated MSC chemotaxis invasion and transendothelial migration induced by IL-1 $\beta$ in response to CXCL9. These results suggest that AMG-487 inhibited binding of CXCL9 and then blocked IL-1 $\beta$-induced chemotaxis invasion and transendothelial migration. There is no significant difference in pretreatment with AMG-487 alone in comparison to the control group. We consider the low expression of CXCR3 on the surface of MSCs before stimulation. Interestingly, AMG-487 inhibits not only the number of migrated MSCs but also the distance of migrated MSCs (Fig. 4c, f). The p38 MAPK activation was involved in IL-1 $\beta$-mediated signal transduction [24, 41, 42]. We further examined the effects of the MAPK family (p38, JNK, ERK1/2) and AKT in IL-1ß-induced CXCR3 expression in MSCs. MSCs were pretreated with SB203580 (p38 MAPK inhibitor), GSK690693 (AKT inhibitor), SP600125 (JNK inhibitor), and U0126 (ERK1/2 inhibitor) and stimulated with IL-1 $\beta$ for $30 \mathrm{~min}$. The immunofluorescence staining results showed that SB203580 can inhibit the CXCR3 expression in MSCs (Additional file 4: Figure S3). Our Western blotting results indicate that pretreatment with p38 MAPK inhibitor SB203580 suppressed IL-1 $\beta$-induced CXCR3 protein expression both in the cytosol and membrane. Moreover, SB203580 reduces the chemotaxis invasion and transendothelial migration induced by IL- $1 \beta$ in MSCs. Thus, it appears that IL- $1 \beta$ enhances the level of CXCR3 expression via p38 MAPK signaling pathway to increase the chemotaxis invasion and transendothelial migration ability of MSCs. There is no significant difference in CXCL9 alone compared to CXCL9 plus SB203580. We consider from this that p38 MAPK signaling is not involved in CXCL9 chemotaxis in MSCs.
Local implantation and systemic intravascular administration are the two available methods of delivery in MSC therapy. Due to risks from transplantation and inefficient migration to the target area, the efficacy of MSC therapy has not been well established. In order to resolve these problems, it is important to increase the migration efficiency of MSCs. For MSCs homing to the target region, MSCs need to express a chemokine receptor that recognizes chemokines produced at injured and inflamed tissues. Much is known about related protein CXCR4 expressed on MSCs through SDF-1/CXCR4 axis in its promotion of MSC migration ability [26]. Bone marrow-derived mesenchymal stem cells migrated to the injured margins and contributed to wound repair through CXCL12/CXCR4 signaling [43]. Moreover, these small molecules of chemokines can be upregulated by TNF and IL-1 in an inflammatory environment [44] and affect stem cell and progenitor cell migration and homing abilities. Through chemokinechemokine receptor axis, homing may provide an important clinical application of MSCs as a cellular vehicle for not only tissue regeneration but also anticancer therapeutics in tumors [45]. In this study, we found that IL-1 $\beta$ upregulated CXCR3 expression on MSC surface and CXCL9 expression in ECs. This effect can increase CXCR3 to CXCL9 binding and promote MSC homing in related diseases.

\section{Conclusions}

In this study, we demonstrated that IL- $1 \beta$ induced CXCR3 expression via 38 MAPK signaling and further increased CXCR3-CXCL9 axis signaling in MSC chemotaxis invasion and transendothelial migration (Fig. 7). The findings of the study hold significance for the future development of MSC therapies targeting inflammatory diseases. Stimulation of MSCs with IL-1 $\beta$ prior to local implantation or intravenous delivery would be one promising potential therapeutic strategy.

\section{Additional files}

\footnotetext{
Additional file 1: Table S1. Sequences of primers used for quantitative real-time polymerase chain reaction experiments. (DOCX $12 \mathrm{~kb}$ )

Additional file 2: Figure S1. Cell viability of MSCs, HUVECs treated with $\| L-1 \beta$, inhibitors, and CXCL9. (A) Cell viability assay for $I L-1 \beta$ and inhibitortreated MSCs in this research. Results were quantified using multimode microplate readers at a wavelength of $545 \mathrm{~nm}$. The data represent mean $\pm \mathrm{SD}(n=3)$. (B) Cell viability assay for IL-1 $\beta$-treated HUVECs. Results were quantified by multimode microplate readers at a wavelength of $545 \mathrm{~nm}$. The data represent mean \pm SD $(n=3)$. (C) Cell viability assay for CXCL9treated in MSCs and HUVECs. Results were quantified by multimode microplate readers at a wavelength of $545 \mathrm{~nm}$. The data represent mean \pm SD $(n=3)$. Statistical analysis was determined by Student's $t$ test and oneway ANOVA. (DOCX 156 kb)

Additional file 3: Figure S2. Short-term and long-term stimulation of $I L-1 \beta$ in MSCs. (A) Immunofluorescence staining of CXCR3 (green) in control MSCs stimulated with IL-1 $\beta$ at 15, 30, and 180 min; cellular nuclei were stained in blue. Scale bar: $50 \mu \mathrm{m}$. (B) MSCs stimulated with IL-1 $\beta$ at 6, 12, and $24 \mathrm{~h}$. Scale bar: $50 \mu \mathrm{m}$. (DOCX $912 \mathrm{~kb}$ )
} 
Additional file 4: Figure S3. Effects of MAPK Family (p38, JNK, ERK1/2) and AKT in IL-1 $\beta$-induced CXCR3 expression in MSCs. Immunofluorescence staining of CXCR3 expression on MSCs. MSCs were pretreated with SB203580 (p38 MAPK inhibitor), GSK690693 (AKT inhibitor), SP600125 (JNK inhibitor), and U0126 (ERK1/2 inhibitor) and stimulated with IL-1 $\beta$ for $30 \mathrm{~min}$. Scale bar: $50 \mu \mathrm{m}$. (DOCX $1219 \mathrm{~kb})$

\section{Abbreviations}

MSCs: Mesenchymal stem cells; ECs: Endothelial cells; HUVECs: Human umbilical vein endothelial cells; IL-1 $\beta$ : Interleukin-1 $\beta$; CXCL9: Chemokine (C-X$C$ motif) ligand 9; CXCR3: CXC chemokine receptor 3; TGF- $\beta 1$ : Transforming growth factor- $\beta 1$; SDF-1: Stromal cell-derived factor 1; TNF-a: Tumor necrosis factor-a

\section{Acknowledgements}

The authors would like to thank Dr. Jiahn-Chun Wu for his advice and comments. They also thank Wenyi Yang for editing the manuscript.

\section{Funding}

This work is financially supported by the Ministry of Science and Technology of the Republic of China, Taiwan, under project number MOST-104-2320-B010-009-MY3 (H.-S. Wang), and by the Ministry of Education, Taiwan, Aim for the Top University Plan, to H.S. Wang.

\section{Authors' contributions}

Y-CG and H-SW contributed to the conception and design, and development of methodology. Y-CG and Y-HC contributed to the acquisition of data. C-PC and $\mathrm{H}-\mathrm{SW}$ contributed to material support and interpretation of data. Y-CG, $\mathrm{Y}-\mathrm{HC}$, and $\mathrm{H}-\mathrm{SW}$ contributed to writing of the manuscript. All authors read and approved the final manuscript.

\section{Ethics approval and consent to participate}

Not applicable.

\section{Consent for publication}

Not applicable.

\section{Competing interests}

The authors declare that they have no competing interests.

\section{Publisher's Note}

Springer Nature remains neutral with regard to jurisdictional claims in published maps and institutional affiliations.

\section{Author details}

'Institute of Anatomy and Cell Biology, School of Medicine, National Yang Ming University, Peitou, Taipei 112, Taiwan, Republic of China. ${ }^{2}$ Division of High Risk Pregnancy, Mackay Memorial Hospital, Taipei, Taiwan, Republic of China.

Received: 12 July 2018 Revised: 7 September 2018

\section{Accepted: 30 September 2018 Published online: 25 October 2018}

\section{References}

1. Kang SK, Shin IS, Ko MS, Jo JY, Ra JC. Journey of mesenchymal stem cells for homing: strategies to enhance efficacy and safety of stem cell therapy. Stem Cells Int. 2012;2012:342968.

2. Muller WA. Getting leukocytes to the site of inflammation. Vet Pathol. 2013: 50(1):7-22.

3. Reshef R, Luger SM, Hexner EO, Loren AW, Frey NV, Nasta SD, et al. Blockade of lymphocyte chemotaxis in visceral graft-versus-host disease. N Engl J Med. 2012;367(2):135-45.

4. Matsushita T, Kibayashi T, Katayama T, Yamashita Y, Suzuki S, Kawamata J, et al. Mesenchymal stem cells transmigrate across brain microvascular endothelial cell monolayers through transiently formed inter-endothelial gaps. Neurosci Lett. 2011;502(1):41-5.

5. Teo GS, Ankrum JA, Martinelli R, Boetto SE, Simms K, Sciuto TE, et al, Mesenchymal stem cells transmigrate between and directly through tumor necrosis factor-alpha-activated endothelial cells via both leukocyte-like and novel mechanisms. Stem Cells. 2012;30(11):2472-86.
6. Fregnan F, Muratori L, Simoes AR, Giacobini-Rovecchi MG, Raimondo S. Role of inflammatory cytokines in peripheral nerve injury. Neural Regen Res. 2012;7(29):2259-66.

7. Deshpande S, James AW, Blough J, Donneys A, Wang SC, Cederna PS, et al. Early expression of local cytokines during systemic Candida albicans infection in a murine intravenous challenge model. Biomedical Rep. 2014;2:869-74.

8. Carrero R, Cerrada I, Lledó E, Dopazo J, García-García F, Rubio MP, et al. IL 1 beta induces mesenchymal stem cells migration and leucocyte chemotaxis through NF-kappaB. Stem Cell Rev. 2012;8(3):905-16.

9. Hengartner NE, Fiedler J, Ignatius A, Brenner RE. IL-1 beta inhibits human osteoblast migration. Mol Med. 2013;19:36-42.

10. Duhen T, Campbell DJ. IL-1 beta promotes the differentiation of polyfunctional human CCR6+CXCR3+ Th1/17 cells that are specific for pathogenic and commensal microbes. J Immunol. 2014;193(1):120-9.

11. O'Boyle G, Fox CR, Walden HR, Willet JD, Mavin ER, Hine DW, et al. Chemokine receptor CXCR3 agonist prevents human T-cell migration in a humanized model of arthritic inflammation. PNAS. 2012;109(12):4598-603.

12. Stanford MM, Issekutz TB. The relative activity of CXCR3 and CCR5 ligands in T lymphocyte migration: concordant and disparate activities in vitro and in vivo. J Leukoc Biol. 2003;74(5):791-9.

13. Lockwood CJ, Huang SJ, Chen CP, Huang Y, Xu J, Faramarzi S, et al. Decidual cell regulation of natural killer cell-recruiting chemokines: implications for the pathogenesis and prediction of preeclampsia. Am J Pathol. 2013;183(3):841-56.

14. Pradelli E, Karimdjee-Soilihi B, Michiels JF, Ricci JE, Millet MA, Vandenbos F, et al. Antagonism of chemokine receptor CXCR3 inhibits osteosarcoma metastasis to lungs. Int J Cancer. 2009;125(11):2586-94.

15. Mikucki ME, Fisher DT, Matsuzaki J, Skitzki JJ, Gaulin NB, Muhitch JB, et al. Non-redundant requirement for CXCR3 signalling during tumoricidal T-cell trafficking across tumour vascular checkpoints. Nat Commun. 2015;6:7458.

16. Groom JR, Luster AD. CXCR3 in T cell function. Exp Cell Res. 2011;317(5):620-31.

17. Oo YH, Banz V, Kavanagh D, Liaskou E, Withers DR, Humphreys E, et al. CXCR3-dependent recruitment and CCR6-mediated positioning of Th-17 cells in the inflamed liver. J Hepato. 2012:57:1044-51.

18. Cameron PU, Saleh S, Sallmann G, Solomon A, Wightman F, Evans VA, et al. Establishment of HIV-1 latency in resting CD4+ T cells depends on chemokineinduced changes in the actin cytoskeleton. PNAS. 2010;107:16934-9.

19. Amatschek $S$, Lucas $R$, Eger $A$, Pflueger M, Hundsberger $H$, Knoll $C$, et al. CXCL9 induces chemotaxis, chemorepulsion and endothelial barrier disruption through CXCR3-mediated activation of melanoma cells. $\mathrm{Br}$ J Cancer. 2011;104(3):469-79.

20. Rabquer BJ, Tsou PS, Hou Y, Thirunavukkarasu E, Haines GK 3rd, Impens AJ, et al. Dysregulated expression of MIG/CXCL9, IP-10/CXCL10 and CXCL16 and their receptors in systemic sclerosis. Arthritis Res Ther 2011;13(1):R18.

21. Loos T, Dekeyzer L, Struyf S, Schutyser E, Gijsbers K, Gouwy M, et al. TLR ligands and cytokines induce CXCR3 ligands in endothelial cells: enhanced CXCL9 in autoimmune arthritis. Lab Investig. 2006;86(9):902-16.

22. Chamberlain G, Smith H, Rainger GE, Middleton J. Mesenchymal stem cells exhibit firm adhesion, crawling, spreading and transmigration across aortic endothelial cells: effects of chemokines and shear. PLoS One. 2011;6(9):e25663.

23. Manna PR, Stocco DM. The role of specific mitogen-activated protein kinase signaling cascades in the regulation of steroidogenesis. J Signal Transduct. 2011;2011:821615.

24. Hu W, Li F, Mahavadi S, Murthy KS. Upregulation of RGS4 expression by IL$1 \beta$ in colonic smooth muscle is enhanced by ERK1/2 and p38 MAPK and inhibited by the PI3K/Akt/GSK3 $\beta$ pathway. AJP-Cell Physiol 2009;Am J Physiol Cell Physiol:296 6 C1310-C20.

25. Huang W, Hu K, Luo S, Zhang M, Li C, Jin W, et al. Herpes simplex virus type 2 infection of human epithelial cells induces CXCL9 expression and CD4+ T cell migration via activation of p38-CCAAT/enhancer-binding protein-beta pathway. J Immunol. 2012;188(12):6247-57.

26. Liu X, Duan B, Cheng Z, Jia X, Mao L, Fu H, et al. SDF-1/CXCR4 axis modulates bone marrow mesenchymal stem cell apoptosis, migration and cytokine secretion. Protein Cell. 2011;2(10):845-54.

27. Gong J, Meng HB, Hua J, Song ZS, He ZG, Zhou B, et al. The SDF-1/CXCR4 axis regulates migration of transplanted bone marrow mesenchymal stem cells towards the pancreas in rats with acute pancreatitis. Mol Med Rep. 2014;9(5):1575-82.

28. Lin CY, Zu CH, Yang CC, Tsai PJ, Shyu JF, Chen CP, et al. IL-1 beta-induced mesenchymal stem cell migration involves MLCK activation via PKC signaling. Cell Transplant. 2015;24(10):2011-28. 
29. Wang HS, Peng ST, Huang CC, Wei HM, Guo YJ, Fu YS, et al. Mesenchymal stem cells in the Wharton's jelly of the human umbilical cord. Stem Cells. 2004;22(7):1330-7.

30. Gupta AK, Rusterholz C, Huppertz B, Malek A, Schneider H, Holzgreve W, et al. A comparative study of the effect of three different syncytiotrophoblast micro-particles preparations on endothelial cells. Placenta. 2005;26(1):59-66.

31. Lin CY. Effect of Interleukin-1 $\beta$ in mesenchymal stem cell migration, [M.S. thesis], Graduate Institute of Anatomy and Cell Biology, National Yang-Ming University, Taipei, Taiwan. 2011.

32. Schneider-Poetsch T, Ju J, Eyler DE, Dang Y, Bhat S, Merrick WC, et al. Inhibition of eukaryotic translation elongation by cycloheximide and lactimidomycin. Nat Chem Biol. 2010;6(3):209-17.

33. Yang CM, Luo SF, Hsieh HL, Chi PL, Lin CC, Wu CC, et al. Interleukin-1 beta induces ICAM-1 expression enhancing leukocyte adhesion in human rheumatoid arthritis synovial fibroblasts: involvement of ERK, JNK, AP-1, and NF-kappa B. J Cell Physiol. 2010;224(2):516-26.

34. Tseng HC, Lee IT, Lin CC, Chi PL, Cheng SE, Shih RH, et al. IL-1 beta promotes corneal epithelial cell migration by increasing MMP-9 expression through NFkappaB- and AP-1-dependent pathways. PLoS One. 2013;8(3):e57955.

35. LO YJ, Liu CM, Wong MY, Hou LT, Chang WK. Interleukin 1 $\beta$-secreting cells in inflamed gingival tissue of adult periondontitis patients. Cytokine. 1999; 11(8):626-33.

36. Chamberlain CS, Leiferman EM, Frisch KE, Brickson SL, Murphy WL, Baer GS, et al. Interleukin expression after injury and the effects of interleukin-1 receptor antagonist. PLoS One. 2013;8(8):e71631.

37. Schmidt A, Ladage D, Steingen C, Brixius K, Schinköthe T, Klinz FJ, et al. Mesenchymal stem cells transmigrate over the endothelial barrier. Eur J Cell Biol. 2006;85(11):1179-88.

38. Steingen C, Brenig F, Baumgartner L, Schmidt J, Schmidt A, Bloch W. Characterization of key mechanisms in transmigration and invasion of mesenchymal stem cells. J Mol Cell Cardiol. 2008;44(6):1072-84.

39. Liu W, Ren HY, Dong YJ, Wang LH, Yin Y, Li Y, et al. Bortezomib regulates the chemotactic characteristics of $T$ cells through downregulation of CXCR3/CXCL9 expression and induction of apoptosis. Int J Hematol. 2012; 96(6):764-72.

40. Vinet J, van Zwam M, Dijkstra IM, Brouwer N, van Weering HR, Watts A, et al. Inhibition of CXCR3-mediated chemotaxis by the human chemokine receptor-like protein CCX-CKR. Br J Pharmacol. 2013;168(6):1375-87.

41. Swaroop S, Sengupta N, Suryawanshi AR, Adlakha YK, Basu A. HSP60 plays a regulatory role in IL-1beta-induced microglial inflammation via TLR4-p38 MAPK axis. J Neuroinflammation. 2016;13:27.

42. Park EJ, Kwon TK. Rottlerin enhances IL-1 beta-induced COX-2 expression through sustained p38 MAPK activation in MDA-MB-231 human breast cancer cells. Exp Mol Med. 2011;43(12):669-75.

43. Hu C, Yong X, Li C, Lü M, Liu D, Chen L, et al. CXCL12/CXCR4 axis promotes mesenchymal stem cell mobilization to burn wounds and contributes to wound repair. J Surg Res. 2013;183(1):427-34.

44. Shin SY, Nam JS, Lim Y, Lee YH. TNFalpha-exposed bone marrow-derived mesenchymal stem cells promote locomotion of MDA-MB-231 breast cancer cells through transcriptional activation of CXCR3 ligand chemokines. J Biol Chem. 2010;285(40):30731-40.

45. Ciavarella S, Dominici M, Dammacco F, Silvestris F. Mesenchymal stem cells: a new promise in anticancer therapy. Stem Cells Dev. 2011;20.

\section{Ready to submit your research? Choose BMC and benefit from:}

- fast, convenient online submission

- thorough peer review by experienced researchers in your field

- rapid publication on acceptance

- support for research data, including large and complex data types

- gold Open Access which fosters wider collaboration and increased citations

- maximum visibility for your research: over $100 \mathrm{M}$ website views per year

At BMC, research is always in progress.

Learn more biomedcentral.com/submissions 